\title{
Występowanie Atropa belladonna (Solanaceae) w województwie śląskim
}

\author{
Adam Stebel i Barbara BACler-ŻBiKowsKa
}

\begin{abstract}
Stebel, A. And Bacler-ŻBikowska, B. 2020. Occurrence of Atropa belladonna (Solanaceae) in the Silesian Province. Fragmenta Floristica et Geobotanica Polonica 27(2): 537-546. Kraków. e-ISSN 2449-8890, ISSN 1640-629X.

ABstract: Atropa belladonna L. is a rare and threatened plant in Silesia Province. The paper lists its stations and gives information about their conservation status. Atropa belladonna is known from about 60 stations here, 24 of which were confirmed after 2010.

Key words: Atropa belladonna, distribution, medicinal plant, Poland, protected plant, Silesia Province

A. Stebel, B. Bacler-Żbikowska, Katedra i Zakład Botaniki Farmaceutycznej i Zielarstwa, Wydziat Nauk Farmaceutycznych, Ślqski Uniwersytet Medyczny w Katowicach, ul. Ostrogórska 30, 41-200 Sosnowiec,Polska; e-mail: astebel@sum.edu.pl; bbacler@sum.edu.pl
\end{abstract}

\section{WSTĘP}

Atropa belladonna L. (pokrzyk wilcza jagoda) jest wysoką, dorastającą do $150 \mathrm{~cm}$ byliną z rodziny psiankowatych Solanaceae. Gatunek reprezentuje podelement europejsko-umiarkowany elementu śródziemnomorskiego i iranoturańskiego (ZAJĄC \& ZAJĄC 2009). Na naturalnych stanowiskach występuje w Europie, północnej Afryce i w zachodniej części Azji. W Polsce rośnie głównie w południowej części kraju, przede wszystkim w niższych położeniach Karpat i Sudetów do wysokości 1100 m n.p.m. Na stanowiskach rozproszonych spotykana jest również na Wyżynie Śląskiej, Wyżynie Małopolskiej, Wyżynie Lubelskiej oraz na Roztoczu (BŁAszczyK 1963; PięKoś-Mirkowa \& Mirek 2006). Siedliskiem występowania pokrzyku są widne lasy i zarośla, zręby i wiatrołomy. Preferuje siedliska żyzne, wilgotne, zacienione, bogate w azot (ZARZYCKI i in. 2002). Jest gatunkiem charakterystycznym dla zespołu ziołorośli porębowych Atropetum belladonnae (MATUSZKIEWICZ 2008).

Atropa belladonna ze względu na zawartość alkaloidów jest rośliną silnie trującą i jednocześnie leczniczą. Pozyskiwanie jej ze stanowisk naturalnych z pewnością przyczyniło się do zubożenia stanowisk, a nawet do zaniku wielu z nich (PięKOŚ-MirkowA \& MireK 2006). W celu umożliwienia kontroli nad zasobami naturalnymi tej rośliny, A. belladonna umieszczona została już na pierwszej liście roślin chronionych Polski (1957 r.), w grupie roślin objętych ochroną częściową (ROZPORZĄDZENIE 1957). W latach 1995-2014 
objęta była ochroną ścisłą (ROZPORZĄDZENIE 1995, 2012), a w 2014 r. ponownie znalazła się na liście gatunków chronionych częściowo (ROZPORZĄDZENIE 2014). W 2016 r. po raz pierwszy umieszczona została na Polskiej czerwonej liście paprotników i roślin kwiatowych (KAŹMIERCZAKOwA i in. 2016) w kategorii NT (gatunek bliski zagrożenia). Do tej pory znajdowała się jedynie na regionalnch ,czerwonych listach”. Na terenie województwa śląskiego uważana jest za gatunek narażony na wyginięcie (VU - PARUSEL \& URBISZ 2012). Na terenie sąsiedniego województwa opolskiego jest gatunkiem zagrożonym wyginięciem (EN - NowAK i in. 2008), a na Wyżynie Małoposkiej krytycznie zagrożonym (CR - BRÓż \& PRZEMYSKI 2009).

Celem pracy jest podanie informacji o rozmieszczeniu i aktualnym stanie zachowania stanowisk Atropa belladonna na terenie województwa śląskiego.

\section{MATERIAE I METODY}

Stanowiska Atropa belladonna z terenu województwa śląskiego znane z literatury i zrewidowanych okazów zielnikowych zestawiono w siatce pól podstawowych $(10 \times 10 \mathrm{~km})$ kartogramu ATPOL. Wszystkie miejsca występowania A. belladonna sprawdzono w terenie. Stanowiska omawianego gatunku uporządkowano w postaci listy zgodnie z kartogramami ATPOL. Ponieważ wiele stanowisk cytowanych jest wielokrotnie przez różnych autorów przyjęto zasadę, że podano tylko publikacje, w których informacja o stanowisku pojawiła się po raz pierwszy, inne prace cytowano tylko w przypadku, kiedy ich autorzy wyraźnie zaznaczali, że potwierdzili dane stanowisko.

Występowanie Atropa belladonna na terenie województwa śląskiego przedstawiono na mapie. Przyjęto dwa przedziały czasowe, w których obserwowano stanowiska pokrzyku - do 2010 r. (białe koła) i od 2010 r. do chwili obecnej (czarne koła). Czarnymi kołami zaznaczone te pola, w których gatunek był obserwowany od 2010 r. przez autorów niniejszej pracy lub innych botaników.

\section{WYNIKI}

\section{Rozmieszczenie geograficzne}

Pierwsze informacje o występowaniu Atropa belladonna na terenie województwa śląskiego pochodzą z okolic Ustronia w Beskidzie Śląskim (WIMMER 1841) i Królewskiej Huty (obecnie centralna część Chorzowa) na Wyżynie Śląskiej (GrABOwsKi 1843). Do tej pory podana została tutaj z około 60 stanowisk, zlokalizowanych w 22 kwadratach ATPOL. Od 2010 r. omawiany gatunek obserwowany był na 24 stanowiskach położonych w 12 kwadratach ATPOL.

Pokrzyk wilcza jagoda występuje na rozproszonych stanowiskach w środkowej i południowej części województwa. Najwięcej stanowisk odnotowano na Pogórzu Cieszyńskim, obejmującym zachodnią część Pogórza Śląskiego (FIEK \& PAX 1889; KoczWARA 1930; KozŁowska 1936; Pelc 1967; Beczata i in. 2005, 2012; Jonderko \& BecZała 2012; FIEDOR i in. 2014). W Beskidach stwierdzony został w Beskidzie Śląskim (WIMMER 1841; Kolbenheyer 1862; KRuPA 1879; CZudeK 1929; MiteK 2006; BinKIEWICZ 2012, 2017; JoNDERKo \& BeCZAŁA 2012) i w Wysokim (Krupa 1879; BiAŁecKA 1982; CiePAŁ i in. 1983) oraz w Kotlinie Żywieckiej (NowAK 1998, 2012), a najwyższe stanowisko obserwowano 
na wysokości 925 m n.p.m. na Plekańce koło Krawcowego Wierchu w Beskidzie Wysokim. BŁASZCZYK (1963) podaje wyższe stanowisko z Klimczoka w Beskidzie Śląskim, 1100 m n.p.m., najprawdopodobniej na podstawie okazów F. Ludery, chociaż na etykiecie zielnikowej brak informacji o wysokości.

Większość pozostałych stanowisk znajduje się na Wyżynie Śląskiej (GRABOWSKI 1843; UeChtritz 1864, 1868, 1878; FieK 1881; SchubE 1902, 1906; CElińSKI \& CZYlOK 1995; CABAŁa \& Zygmunt 2003; Krotoski 2007; Urbisz i in. 1992; Urbisz 2018), a jedno na Wyżynie Krakowsko-Częstochowskiej (KAZnowsKi 1922, 1928). Dwa stanowiska, które uznane zostały za wątpliwe, podane zostały z Wyżyny Woźnicko-Wieluńskiej (Heré́nIAK 1983).

Rozmieszczenie stanowisk pokrzyku wilczej jagody w sieci kartogramów ATPOL na terenie wojwództwa śląskiego przedstawiono na rycinie 1.

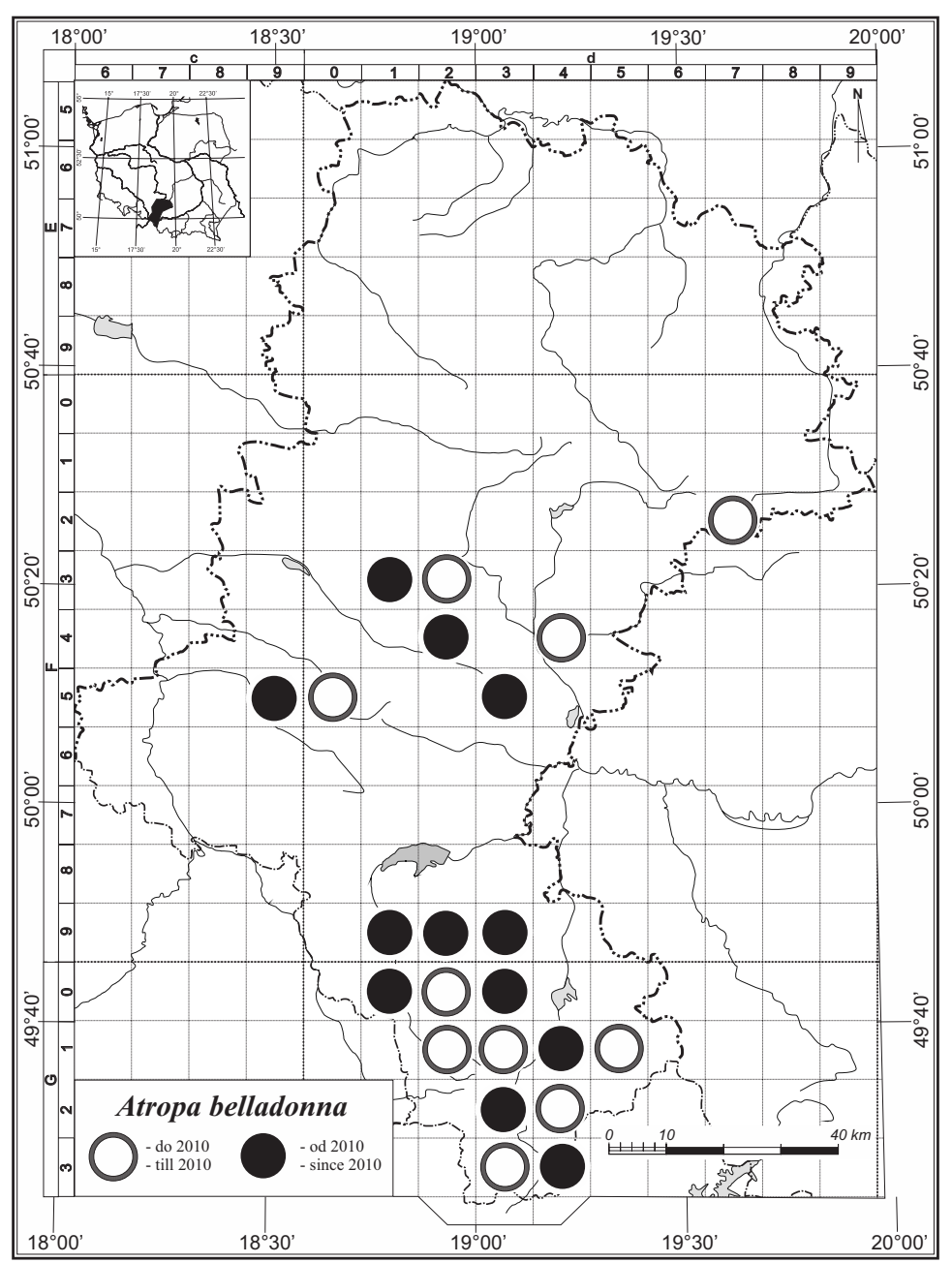

Ryc. 1. Rozmieszczenie Atropa belladonna w województwie śląskim

Fig. 1. Distribution of Atropa belladonna in the Silesian Province 


\section{Warunki występowania i liczebność populacji}

Gatunek notowano głównie z siedlisk zaburzonych, takich jak przydroża, zręby, lasy gospodarcze czy też luki w drzewostanach. Na dwóch ostatnio potwierdzonych stanowiskach wykonano zdjęcia fitosocjologiczne. Pierwsze obejmuje płat lasu gospodarczego w Katowicach-Murckach, natomiast drugie zbiorowisko okrajkowe rozwijające się wzdłuż leśnej drogi w Rybniku-Grabowni.

Zdj. nr 1. Katowice-Murcki, oddz. 472 ; $50^{\circ} 09^{\prime} 06^{\prime \prime} \mathrm{N}, 19^{\circ} 05^{\prime} 23^{\prime \prime} \mathrm{E}, 7.06 .2020$, powierzchnia $50 \mathrm{~m}^{2}$, zwarcie warstw A: 70\%, B: 5\%, C: 70\%, D: 50\%. A: Larix decidua 4, Betula pendula 2; B: B. pendula 1, Larix decidua + ; C: Carex brizoides 3, Atropa belladonna 2, Calamagrostis villosa 2, Oxalis acetosella 2, Pteridium aquilinum 2, Rubus sp. 1, Ajuga reptans +, Impatiens parviflora +, Maianthemum bifolium +, Stellaria longifolia + , Trientalis europaea + , Viola sp.; D: Brachythecium rutabulum 3, B. salebrosum 1, Dicranella heteromalla 1, Polytrichastrum formosum +.

Zdj. nr 2. Rybnik-Grabownia, oddz. $115 ; 50^{\circ} 08^{\prime} 50,4^{\prime \prime} \mathrm{N}, 18^{\circ} 31^{\prime} 52,4^{\prime \prime} \mathrm{E}, 18.08 .2020$, powierzchnia $20 \mathrm{~m}^{2}$, zwarcie warstwy C: 100\%: Urtica dioica 3.3, Solidago gigantea 2.2, Atropa belladonna 2.2, Poa sp. 1.2, Rubus idaeus 1.1, Cardaminopsis arenosa + , Carex brizoides + , Cirsium arvense + , C. lanceolatum +, Erigeron annuus + , Eupatorium cannabinum + , Impatiens parviflora + , Lycopus europaeus + , Mycelis muralis + , Oxalis fontana + , Scrophularia nodosa + .

Liczebność populacji waha się od pojedynczych sztuk (najczęściej) do kilkudziesięciu osobników. Według Jonderki i BeCZAŁy (2012) na Pogórzu Cieszyńskim Atropa belladonna występuje dość licznie. Jej zasoby autorzy ocenili na około pół tysiąca pędów, zastrzegając jednocześnie, że ta liczba w kolejnych sezonach podlega dużym wahaniom. W województwie śląskim najobfitsze stanowisko znajduje się w okolicach Kamiennej Góry w Katowicach-Murckach. Na obszarze około 9 ha obserwowano tu co najmniej kilkanaście skupisk pokrzyku wilczej jagody liczące od kilku do kilkudziesięciu osobników. Największe $\mathrm{z}$ nich znajdują się $\mathrm{w}$ pobliżu starych wyrobisk wapienia. A. belladonna rośnie tu na przydrożach, w prześwietleniach zbiorowisk leśnych, w zbiorowiskach ruderalnych wokół paśnika dla zwierząt oraz na zarośniętym terenie wyrobisk wapieni.

\section{Lista stanowisk}

CF59 Rybnik-Golejów (leg. R. Fritze, Uechtritz 1868); Rybnik-Grabownia, północno-wschodnia część oddz. 115 (KROTOSKI 2007 jako Rybnik-Golejów; not. A. Stebel, 14 osobników na przydrożu leśnej drogi, 18.08.2020); Rybnik-Golejów, projektowany rezerwat „Głębokie Doły”, oddz. 128 (CelińsKI \& CZYLOK 1995; KROTOSKI 2007).

DF27 Smoleń (KAZNOwSKi 1922, 1928).

DF31 Zabrze, Miejski Ogród Botaniczny (URBISZ 2018) - gatunek jest tu uprawiany, nie wiadomo jaki charakter miało cytowane stanowisko.

DF32 Chorzów, Królewska Huta (obecnie centralna część Chorzowa) (GRABOWSKI 1843; leg. C. Dziatzko, 12.07.1889, NowaK \& NowaK 2005).

DF42 Chorzów, zespół przyrodniczo-krajobrazowy „Uroczysko Buczyna” (CABAŁA \& ZYGMUNT 2003; not. A. Stebel, kilka osobników na przydrożu leśnej drogi, 2010); Katowice-Brynów (leg. G. Schneider, Uechtritz 1878); Ruda Śląska-Kochłowice, Las Radoszowski (leg. Englisch, Schube 1906); Ruda Śląska-Nowy Bytom (leg. Nawrath, FIEK 1881).

DF44 Mysłowice, Las Mysłowicki (Uechtritz 1864); Mysłowice-Brzęczkowice (leg. B. Wilk, 25.08.1990, KTU, Urbisz 2018). 
DF50 Rybnik, między Paruszowcem a Kamieniem (leg. Müller \& E. Tischbierek, SchUBE 1906).

DF53 Katowice-Murcki (leg. C. Unverricht, Uechtritz 1877; leg. Istel, Schube 1902); KatowiceMurcki, Kamienna Góra (URBISZ i in. 1992; not. A. Stebel \& B. Bacler-Żbikowska, kilkaset osobników na przydrożach dróg leśnych, w lukach drzewostanu, na siedliskach ruderalnych i w zarośniętym kamieniołomie wapienia, 07.06.2020).

DF91 Góra Bucze (FIEDOR i in. 2014); Skarpa Wiślicka koło Skoczowa (leg. B. Babczyńska-Sendek, 10.06.1978, KTU); Wiślica, terasa Wisły, w Fagetum cieszynicum typicum, NE, 310 m (KozŁowsKA 1936); Wiślica (NAKs 2010 za: JoNDERKo \& BECZAŁa 2012).

DF92 Brenna, potok Barujec, 420 m (Jonderko \& BeCZAŁA 2012); Łazek, stok, 500 m (JonDERKO \& BECZAŁA 2012); Góra Borowina koło Jaworza, północno-zachodni stok, obok niedawno zbudowanej drogi leśnej, 49 46 $42,55^{\prime \prime} \mathrm{N}, 18^{\circ} 56^{\prime} 43,50^{\prime \prime} \mathrm{E}, 491 \mathrm{~m}$ (not. M. Wiśniewski, 19.06.2019), $49^{\circ} 46^{\prime} 31,22^{\prime \prime} \mathrm{N}, 18^{\circ} 56^{\prime} 46,57^{\prime \prime} \mathrm{E}, 560 \mathrm{~m}$ i $49^{\circ} 46^{\prime} 26,39^{\prime \prime} \mathrm{N}, 18^{\circ} 56^{\prime} 44,20^{\prime \prime} \mathrm{E}, 586 \mathrm{~m}$ (not. M. Wiśniewski, 15.08.2020).

DF93 częsty w górach wokół Bielska (KolBENHEYER 1862); Kołowrót (BINKIEwICZ 2017); Kozia Góra, 520 m (BINKIEWICZ 2012, 2017).

DG01 Cisownica (leg. Zabłocka \& Zborek, 19.09.1974, KTU); Cisownica, koło rezerwatu „Zadni Gaj” (leg. A. Sendek, 07.06.1977, KTU); Cisownica, poniżej rezerwatu „Zadni Gaj”, od strony zachodniej (leg. K. Rostański, 07.06.1977, KTU); Cisownica, Las Pazuchy, 500 m (KoczWARA 1930); Cisownica, wzgórze 551, zarośla na skraju lasu chłopskiego (BECZAŁA i in. 2005); Cisownica-Gołaźnia (JoNDERKo \& Beczała 2012); Cisownica-Wędoły (Wendoły) (leg. S. Pelc, 04.07./23.10.1961, KRA, Pelc 1967); Dzięgielów, szczyt wzgórza w kierunku Goleszowa, SW, w Querco-Carpinetum, 417 m (KozŁowsKA 1936); Goleszów (leg. J. Gałuszka, 22.07.1933, KTU); Góra Chełm w Godziszowie, kilka osobników w młodniku jesionowym (BeCZAŁa i in. 2012); Góra Chełm koło Goleszowa, ES, w Querco-Carpinetum, 430 m (KozŁowska 1936); Góra Cis w Cisownicy, kilka osobników w grądzie (BeCZAŁA i in. 2012); Góra Jasieniowa (=Goleszowska Góra) (leg. B. Kotula, FIEK \& PAX 1889); Góra Jasieniowa, w sąsiedztwie dawnego wyrobiska, niedaleko zielonego szlaku turystycznego z Goleszowa na Tuł, 410 m n.p.m. (not. M. Fiedor, 16.07.2017); Góra Jasieniowa w Dzięgielowie, S stoki, łącznie kilkadziesiąt osobników na porębie i w buczynie (BECZAŁA i in. 2012); Góra Tuł w Lesznej Górnej, kilkanaście osobników na skraju lasu (BECZAŁA i in. 2012); Góra Tuł, WN stok od strony Cisownicy, w Fagetum cieszynicum typicum, 580 m (KozŁowsKa 1936); Lipowski Groń, 550-610 m (BINKIEwicz 2017); Machowa (leg. A. Sendek, 07.06.1977, KRA); Malcowa (Jonderko \& BeCZAŁA 2012); Ustroń (WimMER 1841).

DG02 Błatnia (CZUDEK 1929); Klimczok, N zbocza (leg. F. Ludera, 28.06.1938, KRA).

DG03 Lipowa (leg. J. Krupa, 08.1878, KRAM); Palenica koło Skrzycznego, 650 m (BINKIEwICZ 2017); Skrzyczne (Skrzyczeń), lasy lipowskie (KruPa 1879); Skrzyczne, 770 m (BINKIEwICZ 2017); Szyndzielnia (KolBENHEYER 1862); Szyndzielnia, na zboczach (leg. F. Ludera, 15.07.1937, KTU).

DG12/13 okolice Wisły (CZUDEK 1929).

DG14 Duży Grojec, stok południowo-zachodni, 470-575 m (leg. A. Nowak, 22.07.1985, KRAM, NowaK 1998, 2012, not. P. Nejfeld, 2015); Przybór, 750 m (BiaŁeCKA 1982).

DG15 Jeleśnia (leg. ?, 07.1901, KRAM).

DG23 dolina Soły, 490 m (BINKIEwICZ 2017); Góra Zabawa (leg. I. Hola, 29.07.2000, KTU); Rajcza Dolna, stok Małej Zabawy (leg. J. Miłek, 31.08.2005, KRA, MıŁeK 2006); Sucha Góra, stok zachodni, 750 m (BIAŁECKA 1982).

DG24 Sucha Góra, S stok, 750 m (leg. K. Białecka, 01.06.1969, KRA, BIAŁECKA 1982); Lipowska, stok południowo-zachodni, zrąb pod Halą Gawłowską, 770 m (leg. K. Białecka, 28.07.1971, KRA, BIAŁECKA 1982); Lipowska, zarośla (leg. A. Lisik, 1994, KTU).

DG33 Praszywka w Rycerkach (KRUPA 1879); Ujsoły, dolina Danielki (CIEPAŁ i in. 1983; leg. B. Kowalczyk, 06.1993, KTU); Ujsoły, dolina Ujsoły, 520 m (BIAŁECKA 1982); Góra Urówka koło Ujsół (leg. A. Sendek, 16.08.1989, KRA). 
DG34 Plekańka, około 1 km na zachód od krawędzi polany Krawców Wierch, 925 m, 5 osobników kwitnących i owocujących, pobocze leśnej drogi stokowej, roślinność ziołoroślowa (not. J. B. Parusel, 19.07.2016).

\section{Stanowiska błędne i najprawdopodobniej błędne:}

Gliwice (DF30). Stanowisko podane przez SENDKa (1984) i KowalCZYK (2005) za pracą GRABOwSKIEGO (1843) odosi się do Królewskiej Huty (Königshütte), obecnie centralnej części Chorzowa (DF32).

Lipie (DE51). HEREŹNIAK (1993) podaje to stanowisko za pracą magisterską (SŁABOŃ 1978), bez bliższej charakterystyki, nie zachowały się stąd także materiały zielnikowe. ZAJĄC i ZAJĄC (2001) uznali status tego stanowiska za niepewny.

Ruda Śląska-Chebzie (DF 42). Stanowisko odnosi się do Huty Pokój na terenie Rudy Śląskiej-Nowego Bytomia, podane przez FieKa (1881) jako „Huta Pokój koło Chebzia” (Friedenshütte bei Morgenroth), które przez niektórych autorów (WossidLo 1900; SENDEK 1984) zostało uznane jako Chebzie, a przez innych (UrBISZ 2018) jako dwa odrębne, Chebzie i Nowy Bytom.

Zajaczki (DE60). Sytuacja identyczna jak z opisanym powyżej stanowiskiem Lipie z tym, że brak tego stanowiska w pracy ZAJĄC i ZAJĄC (2001). Należy zaznaczyć że w gminie Krzepice nie ma miejscowości Zajączki, są natomiast dwie odrębne wsie: Zajączki Pierwsze i Zajączki Drugie.

Kwadrat DF 13. W pracy ZAJĄC i ZAJĄC (2001) zaznaczono stanowisko którego status określono jako niepewny. Źródła tej informacji nie udało się zlokalizować, być może omyłkowo zaznaczono tu stanowisko Zajączki z pracy HEREźnIAKA (1993), którego nie ma na mapie.

\section{DYSKUSJA}

Atropa belladonna jest do tej pory ważną rośliną leczniczą. Obecnie surowiec dla przemysłu farmaceutycznego pozyskiwany jest z upraw gruntowych, a także hodowli in vitro (STRZELECKA \& KowALSKi 2000; SENDERSKi 2017), w związku z czym zbiór pokrzyku wilczej jagody ze stanu naturalnego dla celów leczniczych nie stanowi zagrożenia dla tej rośliny. Pomimo to, prawie wszędzie jest rośliną rzadką, np. na Pogórzu Ciężkowickim (KORNAŚ i in. 1996) lub bardzo rzadką, np. w Dołach Jasielsko-Sanockich (OKLEJEwICZ 1993), we wschodniej części Kotliny Sandomierskiej (NoBIs 2008) lub we wschodniej części Pogórza Wielickiego (PACYNA 2004). Rzadkość występowania może wynikać zarówno z biologii gatunku, jak również działalności człowieka. A. belladonna od niepamiętnych czasów cieszyła się złą sławą jako roślina trująca (RUMIŃsKA 1983) i z tego powodu niewątpliwie była niszczona w pobliżu siedzib ludzkich. Jak podaje SEŃCZUK (2012), nawet mięso zwierząt, które spożyły liście pokrzyku, może wywołać zatrucia. Inne czynniki negatywnie wpływające na omawiany gatunek związane są z gospodarką leśną. Należą tu m.in. niszczenie runa podczas zrywki drewna, a zwłaszcza szybkie zagospodarowywanie zrębów i wiatrołomów. W województwie śląskim taką sytuację opisano z leśnictwa Ochojec na terenie Rybnika, kiedy to na skutek przeorania zrębu uszkodzono lub zniszczono wiele roślin z liczącej 66 osobników populacji (KROTOSKI 2007). W 2020 r. nie odnaleziono w tym miejscu pokrzyku, natomiast obok przebiegającej niedaleko leśnej drogi przeciwpożarowej stwierdzono znacznie mniejszą populację, liczącą 14 osobników. Pewnym potwierdzeniem obserwacji dotyczących negatywnego wpływu człowieka na omawiany gatunek może być informacja o jego liczniejszym występowaniu (określonym jako dość częste) na słabo obecnie zaludnionym obszarze Bieszczadów Niskich i Otrytu (ZEMANEK 1989). 
Na podstawie uzyskanych wyników badań nad rozmieszczeniem Atropa belladonna w województwie śląskim można stwierdzić, że omawiany gatunek należy tu do coraz rzadszych elemenów flory i przypisana mu kategoria zagrożenia VU (PARUSEL \& URBISZ 2016) jest w pełni uzasadniona. Stanowiska występowania pokrzyku wilczej jagody, o ile jest to możliwe, powinny zostać objęte ochroną. Szczególnie pożądane byłoby utworzenie użytku ekologicznego w okolicach Kamiennej Góry w Katowicach, obszaru należącego do Lasów Państwowych, gdzie populacja A. belladonna jest wyjątkowo obfita.

Podziękowania. Autorzy dziękują kuratorom zielników KRA, KRAM i KTU za umożliwienie rewizji okazów Atropa belladonna. Panom mgrowi Markowi Fiedorowi, Tomaszowi Jonderko i Mirosławowi Wiśniewskiemu dziękujemy za informacje o występowaniu A. belladonna na Śląsku Cieszyńskim, dr. Pawłowi Nejfeldowi za informację o tym gatunku na górze Grojec koło Żywca a dr. Jerzemu B. Paruselowi za informację o występowaniu pokrzyku wilczej jagody koło Krawcowego Wierchu. Praca wykonana została w ramach badań statutowych Katedry i Zakładu Botaniki Farmaceutycznej i Zielarstwa ŚUM: KNW-1-057/K/9/O.

\section{LITERATURA}

Beczata T., Chwastek E. \& WiKa S. 2005. Nowe stanowiska chronionych i zagrożonych gatunków roślin naczyniowych na Pogórzu Cieszyńskim. - Badania Fizjograficzne nad Polską Zachodnią, Seria B - Botanika 54: 125-128.

Beczata T., Chwastek E. \& Wika S. 2012. Nowe stanowiska rzadkich i chronionych roślin naczyniowych na Pogórzu Cieszyńskim. - Badania Fizjograficzne nad Polską Zachodnią, Seria B - Botanika 61: $113-122$.

BiAŁECKA K. 1982. Rośliny naczyniowe Grupy Pilska w Beskidzie Żywieckim. - Zeszyty Naukowe Uniwersytetu Jagiellońskiego 618, Prace Botaniczne 10: 1-149.

BINKIEWICZ B. 2012. Notatki florystyczne z Beskidu Śląskiego. - Fragmenta Floristica et Geobotanica Polonica 19(1): 180-181.

BinKIEWICZ B. 2017. Rośliny naczyniowe Beskidu Śląskiego. s. 294. Polska Akademia Nauk, Uniwersytet Jagielloński, Warszawa - Kraków.

BŁASZCZYK H. 1963. Rodzina Solanaceae psiankowate. - W: B. PAwŁowSKI (red.), Flora polska. Rośliny naczyniowe Polski i ziem ościennych. 10, s. 217-229. Państwowe Wydawnictwo Naukowe, Warszawa - Kraków.

Bróż E. \& Przemyski A. 2009. The red list of vascular plants in the Wyżyna Małopolska Uplannd (S Poland). - W: Z. MireK \& A. Nikiel (red.), Rare, relict, and endangered plants and fungi in Poland. s. 123-136. W. Szafer Institute of Botany, Polish Academy of Sciences, Kraków.

CabaŁa S. \& Zygmunt J. 2003. Przyroda zespołu przyrodniczo-krajobrazowego „Uroczysko Buczyna” w Chorzowie. Przewodnik po ścieżce dydaktycznej. Przyrodnicze Ścieżki Dydaktyczne Województwa Śląskiego 9: 1-92.

CELIŃski F. \& CZYLOK A. 1995. Różnorodność biologiczna i przyrodniczo-krajobrazowa „Uroczyska Głębokie Doły” koło Rybnika. - Scripta Rudensia 5: 1-51.

Ciepą R., Magiera A. \& Klama H. 1983. Materiały do flory roślin naczyniowych i zespoły chwastów segetalnych doliny Danielki w Beskidzie Żywieckim. - Prace Naukowe Uniwersytetu Śląskiego 541, Acta Biologica 11: 184-194.

Czudek A. 1929. Osobliwości i zabytki przyrody województwa śląskiego. Państwowa Rada Ochrony Przyrody, Kraków 19: 1-78. 
Fiedor M., Henel A., Becząa T. \& Jonderko T. 2014. Flora. - W: R. W. MysŁajek (red.), Monografia przyrodnicza góry Bucze, s. 38-58. Gmina Brenna, Brenna.

FIEK E. 1881. Flora von Schlesien preussischen und österreichischen Antheils, enthaltend die wildwaschsenden, verwilderten und angebauten Phanerogamen und Gefäss-Cryptogamen. s. $164+571$. J. U. Kern's Verlag, Breslau.

FiEK E. \& PAX F. 1889. Resultate der Durchforschung der schlesischen Phanerogamenflora im Jahre 1888. - Jahres-Bericht der Schlesischen Gesellschaft für vaterländische Cultur 66: 174-206.

Grabowski H. 1843. Flora von Oberschlesien und dem Gesenke. Mit Berücksichtigung der geognostischen Boden-und Höhen-Verhältnisse. s. 451. Verlag von A. Gosehorsky, Breslau.

HeREźniaK J. 1993. Stosunki geobotaniczno-leśne północnej części Wyżyny Śląsko-Krakowskiej na tle zróżnicowania i przemian środowiska. - Monographiae Botanicae 75: 1-368.

Jonderko T. \& BeczaŁa T. 2012. Pokrzyk wilcza jagoda na Pogórzu Cieszyńskim i w północnej części Beskidu Śląskiego. - Przyrodnik Ustroński 11: 126-129.

KAZNOWSKI K. 1922. Przyczynek do flory okolic Zawiercia i Wyżyny Kielecko-Sandomierskiej. - Kosmos 47: 101-104.

KAZNowsKi K. 1928. Rośliny naczyniowe okolic Zawiercia. - Sprawozdanie Komisji Fizjograficznej Polskiej Akademii Umiejętności 62: 185-207.

Kaźmierczakowa R., Bloch-OrŁowska J., Celka Z., Cwener A., Dajdok Z., Michalska-Hejduk D., Pawlikowski P., SzCZę́ŚniaK E. \& Ziarnek K. 2016. Polska czerwona lista paprotników i roślin kwiatowych. s. 44. Instytut Ochrony Przyrody Polskiej Akademii Nauk, Kraków.

KoczWARA M. 1930. Szata roślinna Beskidu Ustrońskiego. Wydawnictwo Muzeum Śląskiego w Katowicach, Dział III, 1: 1-66.

KOLBENHEYER C. 1862. Vorarbeiten zur einer Flora von Teschen und Bielitz. - Verhandlungen der kaiserlich-königlichen zoologisch-botanischen Gesellschaft in Wien 12: 1185-1220.

Kornaś J., Medwecka-Kornaś A. \& TowPasz K. 1996. Rośliny naczyniowe Pogórza Ciężkowickiego (Karpaty Zachodnie). - Zeszyty Naukowe Uniwersytetu Jagiellońskiego 1200, Prace Botaniczne 28: $1-170$.

KowALCZYK B. 2005. Chronione gatunki roślin naczyniowych północnej części Kotliny Raciborskiej i okolic. - Fragmenta Floristica et Geobotanica Polonica 12(1): 97-111.

KozŁowska A. 1936. Charakterystyka zespołów leśnych Pogórza Cieszyńskiego. - W: Biocenoza lasów Pogórza Cieszyńskiego. Wydawnictwa Śląskie, Polska Akademia Umiejętności, Prace Biologiczne 1: $1-78$.

Krotoski T. 2007. Pokrzyk wilcza jagoda w Rybniku. - Przyroda Górnego Śląska 50: 16.

KRUPA J. 1879. Stosunki florystyczne dorzecza Soły. - Sprawozdanie Komisji Fizyjograficznej Akademii Umiejętności 13: 146-182.

MatuszKiewicz W. 2008. Przewodnik do oznaczania zbiorowisk roślinnych Polski. s. 536. Wydawnictwo Naukowe PWN, Warszawa.

MıŁEK J. 2006. Rzadkie i interesujące gatunki roślin z pasma Wielkiej Raczy w Beskidzie Żywieckim. - Fragmenta Floristica et Geobotanica Polonica 13(2): 425-427.

NoBIs A. 2008. Rośliny naczyniowe wschodniej części Kotliny Sandomierskiej. - Prace Botaniczne 42: $1-341$.

NowaK A. \& NowaK S. 2005. Katalog Zielnika Roślin Naczyniowych Muzeum Śląska Opolskiego. s. 147. Muzeum Śląska Opolskiego w Opolu, Opole.

NowAK A. K. 1998. Rzadsze i ginące rośliny spotykane na Grojcu koło Żywca (Karpaty Zachodnie). - Fragmenta Floristica et Geobotanica Series Polonica 5: 47-54. 
NowAK K. A. 2012. Flora naczyniowa Grojca. Monografia geobotaniczna. s. 1012. Nakład własny, Warszawa - Żywiec (Grojec).

Nowak A., Nowak S. \& SpaŁeK K. 2008. Red list of vascular plants of Opole Province. - Nature Journal 41: $141-158$.

OKLEJEwICZ K. 1993. Flora Dołów Jasielsko-Sanockich. - Zeszyty Naukowe Uniwersytetu Jagiellońskiego 1103, Prace Botaniczne 26: 1-165.

Pacyna A. 2004. Rośliny naczyniowe wschodniej części Pogórza Wielickiego i przylegającej części Beskidów (Karpaty Zachodnie). - Prace Botaniczne 38: 1-367.

PARusel J. B . \& URBisz A. (red.). 2012. Czerwona lista roślin naczyniowych województwa śląskiego. - Raporty, Opinie 6: 105-177.

Pelc S. 1967. Rośliny naczyniowe Pogórza Cieszyńskiego. - Rocznik Naukowo-Dydaktyczny WSP w Krakowie 28: 109-208.

PięKoś-Mirkowa H. \& Mirek Z. 2006. Rośliny chronione. Wydanie II. s. 368. Multico Oficyna Wydawnicza, Warszawa.

RozPoRZĄDZENIE Ministra Leśnictwa i Przemysłu Drzewnego z dnia 28 lutego 1957 r. w sprawie wprowadzenia gatunkowej ochrony roślin (Dz.U. z 1957 r. nr 15, poz. 78).

RozPORZĄDZENIE Ministra Ochrony Środowiska, Zasobów Naturalnych i Leśnictwa z dnia 6 kwietnia 1995 r. w sprawie wprowadzenia ochrony gatunkowej roślin (Dz.U. z 1995 r. nr 41, poz. 214).

RozPORZĄDZENIE Ministra Środowiska z dnia 5 stycznia 2012 r. w sprawie ochrony gatunkowej roślin (Dz. U. 2012 r., poz. 81).

RozPORZĄDZENIE Ministra Środowiska z dnia 9 października 2014 r. w sprawie ochrony gatunkowej roślin (Dz. U. 2014 r., poz. 1409).

RumińSKA A. 1983. Rośliny lecznicze. Podstawy biologii i agrotechniki. Wyd. 3. s. 550. Państwowe Wydawnictwo Naukowe, Warszawa.

SchuBE T. 1902. Ergebnisse der Durchforschung der schlesischen Gefässpflanzenwelt im Jahre 1901. - Jahres-Bericht der Schlesischen Gesellschaft für vaterländische Cultur 79: 23-37.

SchuBE T. 1906. Ergebnisse der Durchforschung der schlesischen Gefässpflanzenwelt im Jahre 1905. - Jahres-Bericht der Schlesischen Gesellschaft für vaterländische Cultur 83: 75-95.

SEndeK A. 1984. Rośliny naczyniowe Górnośląskiego Okęgu Przemysłowego. s. 138. Opolskie Towarzystwo Przyjaciół Nauk, Państwowe Wydawnictwo Naukowe, Warszawa - Wrocław.

SEndERSKi M. E. 2017. Prawie wszystko o ziołach i ziołolecznictwie. s. 656. Wydawca Mateusz E. Senderski, Podkowa Leśna.

SEŃCZuK W. (red.). 2012. Toksykologia współczesna. s. 996. Wydawnictwo Lekarskie PZWL, Warszawa.

StrZELECKA H. \& KowALSKI J. 2000. Encyklopedia zielarstwa i ziołolecznictwa. s. 645. Wydawnictwo Naukowe PWN, Warszawa.

UeChTRITZ R. 1864. Nachträge zur schlesischen Flora (III.). - Verhandlungen des Botanischen Vereins für die Provinz Brandenburg und die Angrenzenden Länder 5: 98-129.

UechtRItz R. 1868. Beitrage zur Schlesischen Flora (V.). - Verhandlungen des Botanischen Vereins für die Provinz Brandenburg und die Angrenzenden Länder 10: 149-169.

UeChTRITZ R. 1877. Die wichtigeren Ergebnisse der Erforschung der schlesischen Phanerogamenflora im Jahre 1876. - Jahres-Bericht der Schlesischen Gesellschaft für vaterländische Cultur 54: 155-195.

UeChTRITZ R. 1878. Die wichtigeren Ergebnisse der Erforschung der schlesischen Phanerogamenflora im Jahre 1877. - Jahres-Bericht der Schlesischen Gesellschaft für vaterländische Cultur 55: 172-187.

Urbisz A. 2018. Chronione rośliny naczyniowe Wyżyny Śląskiej. s. 277. Centrum Dziedzictwa Przyrody Górnego Śląska, Katowice. 
Urbisz A., FoJCiK B., Rostański A. \& TokARSKA-GuZIK B. 1992. Zasługujące na uwagę stanowisko wawrzynka wilczełyko (Daphne mezereum L.) w kompleksie lasów murckowskich w obrębie miasta Katowice. - Kształtowanie Środowiska Geograficznego i Ochrona Przyrody na Obszarach Uprzemysłowionych i Zurbanizowanych 5: 45-48.

WIMMER F. 1841. Flora von Schlesien. s. 464. Verlag von Ferdinand Hirt, Breslau.

WossidLo P. 1900. Flora von Tarnowitz. s. 181. Verlag von A. Kothe, Tarnowitz.

ZAJĄC A. \& ZAJĄC M. (red.). 2001. Atlas rozmieszczenia roślin naczyniowych w Polsce. s. xii + 714. Nakładem Pracowni Chorologii Komputerowej Instytutu Botaniki Uniwersytetu Jagiellońskiego, Kraków.

ZAJĄC M. \& ZAJĄC A. 2009. Elementy geograficzne rodzimej flory Polski. s. 94. Nakładem Pracowni Chorologii Komputerowej Instytutu Botaniki Uniwersytetu Jagiellońskiego, Kraków.

Zarzycki K., TrZcińska-Tacik H., RóŻański W., Szeląg Z., WoŁek J., KorZeniak U. (red.). 2002. Ecological indicator values of vascular plants of Poland. s. 183. Instytut Botaniki im. Władysława Szafera PAN, Kraków.

ZemaneK B. 1989. Rośliny naczyniowe Bieszczadów Niskich i Otrytu. - Zeszyty Naukowe Uniwersytetu Jagiellońskiego 965, Prace Botaniczne 20: 1-185.

\section{SUMMARY}

In Poland, Atropa belladonna L. is a rare plant under partial species protection, growing in the southern part of the country, mainly in lower parts of the Carpathians and Sudetes up to $1100 \mathrm{~m}$ a.s.l. The paper provides information on the distribution and current state of preservation of its stations in Silesia Province. The sites of this species known from the literature and revised herbarium specimens were checked in the field. In this area, A. belladonna has been given so far from about 60 stations located in 22 ATPOL squares. Since 2010, the species has been observed at 24 sites located in 12 ATPOL squares (Fig. 1). It occurs in the central and southern parts of the province. The largest number of records are from the western part of the Silesian Foothills (so called Pogórze Cieszyńskie). It is rare in other regions: the Silesian Upland, Kraków-Częstochowa Upland and Beskids. The population sizes range from single plants (most often) to several dozen individuals. The most numerous population, in Katowice-Murcki, has several hundred plants. Atropa belladonna is disappearing from the flora of the Silesian Province.

Wptynęto: 29.10.2020 r.; przyjęto do druku: 04.12.2020 r. 